DOI 10.18551/rjoas.2021-08.09

\title{
COMPARISON OF CHERRY LEAVES (MUTINGIA CALABURA) AS FEED COMPONENT AGAINST THE LOW DENSITY OF LIPOPROTEIN BLOOD, HIGH BLOOD LIPOPROTEIN DENSITY, PROTEIN AND FAT CONTENTS OF MOJOSARI DUCK MEAT
}

\author{
Wirjaatmadja Roeswandono*, Yanestria Sheila Marty, Prakoso Yos Adi, \\ Ningrum Siti Gusti \\ Faculty of Veterinary Medicine, University of Wijaya Kusuma Surabaya, Surabaya, Indonesia \\ *E-mail: atmajaros@uwks.ac.id
}

\begin{abstract}
This study compares the addition of cherry leaf meal (Mutingia calabura) in the feed to the levels of low-density lipoprotein and high-density lipoprotein, fat, and protein content of Mojosari male duck meat. The samples used were 27 male Mojosari ducks divided into three treatment groups and nine replications - the first treatment group (P1), including nine ducks given bran feed for 15 days. The second treatment group (P2) is nine ducks given $6 \%$ cherry leaf flour for 15 days. The third treatment group (P3) is nine ducks given $8 \%$ cherry leaf flour for 15 days. The variables measured were serum LDL and HDL as well as levels of fat and protein in meat. The results of the study were P1 LDL values showed $60.20 \pm 0.89 ; P 2: 58.67$ \pm 0.83 ; P3: $58.24 \pm 0.79(P>0.05)$, while the HDL value $P 1$ showed $59.10 \pm 0.74 ; P 2: 55.82$ \pm 0.69 ; P3 showed $55.12 \pm 0.67(P>0.05)$. The results of the study, the protein value of meat P1 showed $8.38+0.32$; P2 showed $11.04+0.11$; and P3 showed $12.00+0.14(P<0.01)$ while the value of meat fat was P1 showed $18.72+0.47$; P2 showed $16.89+0.42$; and P3 showed $16.54+0.26(P<0.01)$. This research concludes that the addition of cherry leaf flour in the feed does not affect the blood LDL and HDL levels but does affect the protein and fat levels of Mojosari male duck meat.
\end{abstract}

\section{KEY WORDS}

Veterinary, animal nutrition, poultry, health.

Duck production can play a major role in the agricultural economy (Adzitey \& Adzitey, 2015). Asian countries alone contribute $84.2 \%$ of total duck meat produced globally (Biswas et al., 2019). Driven by consumer demand for duck meat consumption is the increasing number of duck stalls on the side of the road, catering, restaurants, and restaurants often providing processed portions of duck meat (Lembong et al., 2015; Sulistyoningsih, 2018). Duck meat has a higher muscle fiber content in breast meat than chicken and is considered red meat (Onbaşilar \& Yalcin, 2018). Moreover, due to a higher fat content than chicken, duck meat can be less appreciated by the consumer (Amaral et al., 2015). Also, consumption of duck meat has considerable risk, namely an increase in cholesterol levels in consumers. It is feared that it will cause obesity and atherosclerosis diseases such as coronary heart disease, hypertension, and stroke. Hence, it is fundamental to explore germplasm as an alternative to developing novel value-added feed for ducks.

Mojosari duck is a type of duck relatively common in the community for meat or eggs because it tastes pretty delicious. This duck is small compared to other cultivated ducks but has a medium egg size. Mojosari ducks that are usually in rural areas are often cared for properly and given food from the leftovers of the farmer's family, sometimes also given rice snail feed (Putra et al., 2016). On the other hand, the cherry plant (Mutianga calabura) is a plant that is often found in rural areas. This plant is easy to grow so that it can be appropriately cultivated. The leaves of $M$. calabura can be a solution in the management of high cholesterol in duck meat. $M$. calabura have various contents such as vitamin $C 11.21$ $\mathrm{mg} / \mathrm{g}$, flavonoids $42.61 \mathrm{mg} / \mathrm{g}$, vitamin E $0.41 \mathrm{mg} / \mathrm{g}$, 61, polyphenols $23.06 \mathrm{mg} / \mathrm{g}$, protein 6.21 $\mathrm{mg} / \mathrm{g}$ and carbohydrates $194.0 \mathrm{mg} / \mathrm{g}$ and rich in anti-oxidants (Nagara, 2015; Putri et al., 2018). M. calabura is expected to be a source of additional feed in the ration because $M$. 
calabura contains flavonoids, alkaloids, and saponins, reducing cholesterol levels (Zakaria et al., 2011).

Furthermore, there is almost no data available on using $M$. calabura in the duck feed. The purpose of this study was to evaluate and compare low-density lipoprotein (LDL), blood high-density lipoprotein (HDL), protein content, and fat Mojosari male duck meat. The present study may give information to consumers, healthcare professionals, and feed manufacturers. These findings could be as an alternative to develop novel value-added feed for ducks.

\section{MATERIALS AND METHODS OF RESEARCH}

This type of research is a type of experimental research with a completely randomized design (CRD) (Zhang et al., 2011). In this study, ducks were divided into three treatment groups and nine replications with individual cages. In this study, the samples used were male ducks aged three days with a weight of 100-200 grams. As many as 27 ducks were obtained from the village of Mojosari Mojokerto, East Java. The sampling technique used was simple random sampling, a sampling technique in which each duck was grouped randomly and not because of subjective considerations. In the research conducted, there were three observed variables. The independent variable is the concentration of cherry leaf flour. On the other hand, The dependent variables include blood serum LDL and HDL, meat fat, and protein levels. Control variables include age, weight, sex, and environment.

A total of five kilograms of cherry leaves obtained from the Lamongan area are dried and aerated for \pm two days so that the active compounds contained in the cherry leaves are not lost due to sunlight. The leaves are then crushed using a blender until a powder-like formation is obtained with a smooth texture. The fine powder is weighed according to the predetermined feed concentration.

This study used 27 male Mojosari ducks aged three days with a weight of 100-200 grams. The adaptation process was carried out for two weeks so that the animal conditions were stable and given standard feed and ad libitum drinking water. After going through the adaptation process, the treatment process is carried out, namely feeding cherry leaf flour. The three groups of treatment ducks used in this study can be described as follows: 1) the control group (P1) consisted of 9 ducks only given standard feed (bran) once a day for 30 days; 2) the second group (P2) consisted of 9 ducks which were given $94 \%$ standard feed and $8 \%$ cherry leaf meal once a day for 30 days, and 3 ) the third group (P3) consisted of 9 ducks which were given $92 \%$ standard feed and $10 \%$ cherry leaf meal once a day for 30 days. On the 30th day, a sample collection was carried out by collecting duck blood through the veins aseptically using an alcohol swab and a $3 \mathrm{ml}$ syringe, after which the blood that flowed out was collected to obtain serum. The obtained serum was then examined using a spectrophotometer in the Clinical Pathology laboratory, The Faculty of Veterinary Medicine, Universitas Wijaya Kusuma Surabaya. At the same time, the analysis of fat and protein content of duck meat was carried out in the Veterinary Public Health Laboratory, The Faculty of Veterinary Medicine, Universitas Wijaya Kusuma Surabaya. Animal experimental procedures were performed with the approval of the Animal Ethics Research Committee of The Faculty of Veterinary Medicine, Universitas Wijaya Kusuma Surabaya (19-KKE).

The data obtained from the research results were then analyzed using analysis of variance (ANOVA).

\section{RESULTS OF STUDY}

A total of 27 male Mojosari ducks were used in this study as experimental animals (Figure 1). This research also succeeded in developing the potential of $M$. calabura (Figure 2) into cherry leaf flour (Figure 3 ) as a feed additive. Table 1 shows the mean levels of LDL and HDL in Mojosari duck blood after treatments in the present study. Based on the ANOVA test, there was no significant difference in reducing LDL levels in each treatment group $(P>$ 
0.05). It indicates that the addition of $M$. calabura in duck feed did not affect reducing LDL and HDL in the blood of Mojosari ducks after 30 days.

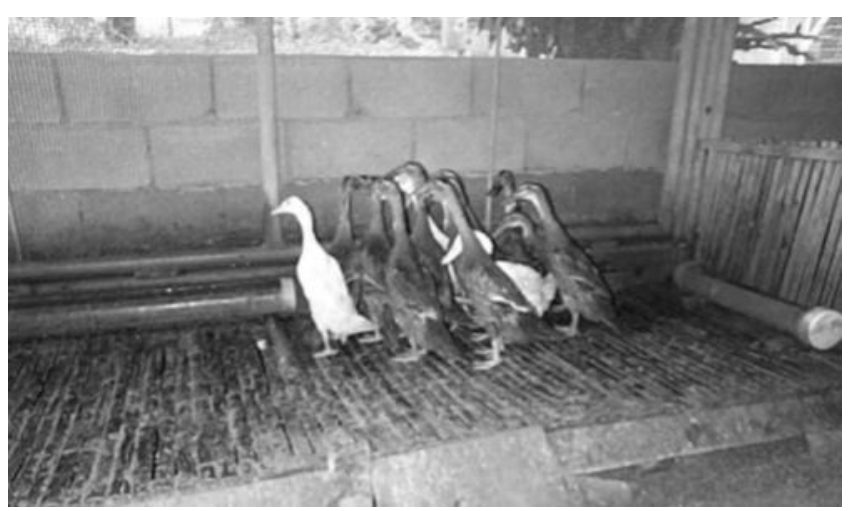

Figure 1 - Mojosari ducks

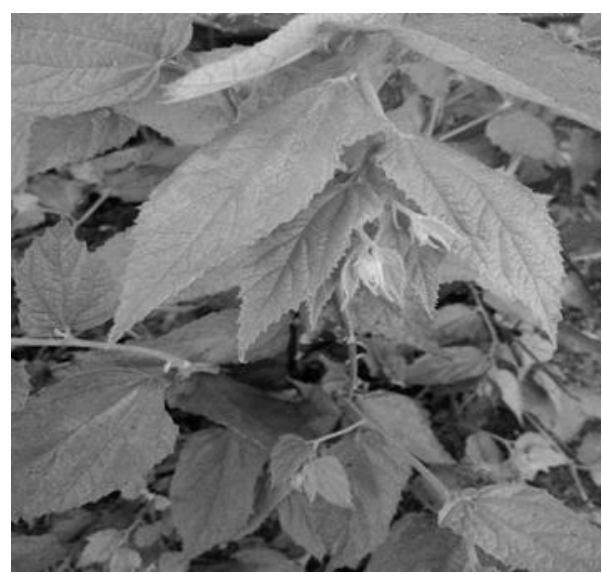

Figure $2-M$. calabura

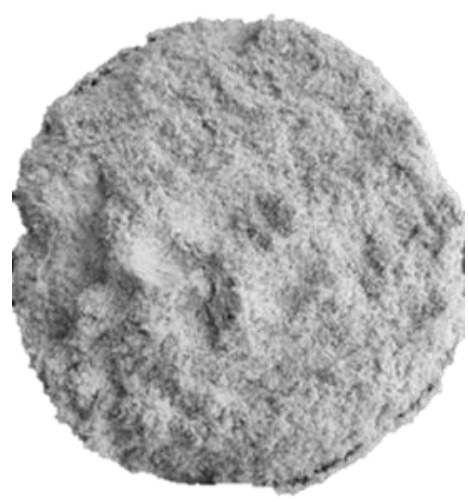

Figure 3 - Cherry leaf flour

Table 1 - Average levels of LDL and HDL in Mojosari duck blood after 30 days of feeding

\begin{tabular}{lll}
\hline \multirow{2}{*}{ Treatment } & \multicolumn{2}{l}{ Mean \pm Standard Deviation } \\
\cline { 2 - 3 } & $L D L$ & $H D L$ \\
\hline P1 $(0 \%)$ & $60.20 \pm 0.89$ & $55.12 \pm 0.67$ \\
P2 $(6 \%)$ & $58.67 \pm 0.83$ & $55.82 \pm 0.69$ \\
P3 (8\%) & $58.24 \pm 0.79$ & $59.10 \pm 0.74$ \\
\hline
\end{tabular}

Table 2 summarises the mean of protein and fat from Mojosari Duck's meat after treatments for 30 days. The mean P3 contained a higher level $(p<0.01)$ of protein than P1 
and P2. In addition, the mean of Mojosari Duck meat fat content indicates significant differences between P2 and P1, but P2 did not differ ( $p>0.05)$ with P3.

Table 2: Average levels of protein and fat content in Mojosari duck meat after 30 days of feeding

\begin{tabular}{lll}
\hline Treatment & \multicolumn{2}{l}{ Mean \pm Standard Deviation } \\
\cline { 2 - 3 } & Protein & Fat \\
\hline P1 $(0 \%)$ & $8.38 \pm 0.32^{\mathrm{a}}$ & $18.72 \pm 0.47^{\mathrm{a}}$ \\
P2 (6\%) & $11.04 \pm 0.11^{\mathrm{b}}$ & $16.89 \pm 0.42^{\mathrm{b}}$ \\
P3 (8\%) & $12.00 \pm 0.14^{\mathrm{c}}$ & $16.54 \pm 0.26^{\mathrm{b}}$ \\
\hline
\end{tabular}

${ }^{a-c}$ Across treatments, means superscripts differ significantly $(p<0.01)$.

\section{DISCUSSION OF RESULTS}

Hyperlipidemia is a risk factor for coronary heart disease and stroke (Alloubani et al., 2020). It can be seen from the results of the lipid profile. Currently, prevention of hyperlipidemia can be done by natural means called phytopharmaceuticals (Nooreen et al., 2018). One of them is cherry leaf extract which contains flavonoids, saponins, and tannins (Nurhuda et al., 2020) to improve lipid profiles in the blood. Flavonoids inhibit cholesterol synthesis by inhibiting HMG-CoA reductase (Baskaran et al., 2015). Saponins and Tannins work by inhibiting cholesterol and triglycerides in the intestines (Adriani 2013). This study succeeded in developing a feed additive in cherry leaves flour to improve the quality of duck meat. Cherry leaves ( $M$. calabura) well-known contain flavonoid compounds, saponins, and tannins, which are productive as antihyperlipidemic (Listiantini, 2017). Various doses of cherry leave flour were added to the commercial feed of Mojosari Duck in this study. The result showed cherry leaves $(M$. calabura) could decrease LDL levels but no significant difference ( $p>0.05$ ) between treatments. These results show that the M. calabura concentration in the feed mixture could not significantly reduce LDL in duck blood within 30 days. Though $M$. calabura contains potential substances as an antihyperlipidemic, cherry leaves were not effective in lowering LDL in normal Mojosari ducks. Listianti (2017) found that cherry leaves can reduce dyslipidemia but are not significant. The LDL level in the present study agreed with the previous study (Sopandi et al., 2019) that using M. calabura in rats with hyperlipidemia was not effective. However, they showed that the combination of $M$. calabura and Cayratia trifolia effectively prevented and avoided other effects of high cholesterol.

It is known that different types of flavonoids can lower LDL cholesterol levels with different abilities (Hirano et al., 2001). The flavonoids, naringenin, and hesperitin can inhibit the activity of ACAT (cholesterol acyltransferase) and MTP (microsomal transfer protein), where ACAT and MTP are responsible for the synthesis and esterification of cholesterol in the liver (Wilcox et al., 2001). The flavanones in orange juice were also able to lower human LDL cholesterol levels (Franke et al., 2005), while the flavonoids in black tea did not lower LDL cholesterol levels (McAnlis et al., 1998). The type of flavonoid in cherry leaves flour is not known not to explain LDL cholesterol levels. One of the weaknesses of this study is that the type of flavonoid contained in cherry leaves flour was not examined. This study concluded that cherry leaves flour can not reduce LDL cholesterol levels.

Similarly, the results of testing on HDL in this study, the increase in HDL that occurred in the blood of Mojosari ducks was not significant. Layli et al., (2017) also found the same results where cherry leaf extract could not increase HDL cholesterol levels. Other studies have shown that various types of flavonoid compounds given the same dose have different effects on increasing HDL cholesterol levels (Zou et al., 2005; van Dam et al., 2013). In addition, antioxidants in phytochemical compounds may affect the Apolipoprotein (Apo) Al gene (Mooradian et al., 2006). Apo Al is the main structural protein of HDL cholesterol (Mangaraj et al., 2016). Several antioxidants in high concentrations can reduce the activity of 
the Apo A-I promoter (Mooradian et al., 2006). Giving antioxidants at high doses is possible to reduce HDL cholesterol levels (Bohm, 2012). Further research is needed to determine the ability of flavonoids in EDK to increase HDL cholesterol levels.

Puspasari et al., (2016) found that cherry leaf extract affected improving the lipid profile levels of hyperlipidemic white mice with the best dose at a dose of $6(\mathrm{mg} / 200 \mathrm{gBW} / \mathrm{day})$ with a percentage of total cholesterol improvement of $65 \%$, TG $79 \%$, LDL $79 \%$, and HDL $75 \%$. In contrast, Marinda (2016) showed that cherry fruit could reduce hyperlipidemia. It indicates that fruit has a high concentration of compounds for reducing hyperlipidemia. Moreover, Wiyati et al., (2020) showed that cherry leaves extract (M. calabura) with the dose of 600 $\mathrm{mg} / \mathrm{KgBB}$ had the best activity in reducing total cholesterol, LDL, and triglyceride levels. It indicates that the use of $\mathrm{M}$. calabura to reduce hyperlipidemia depends on the extraction method, doses, host, and combination with other compounds. The use of cherry leaves standalone in duck feed for the prevention of hyperlipidemia was not recommended.

Although the administration of cherry leaf flour did not show a significant decrease in LDL and an increase in HDL in this study, cherry leaf flour was able to increase the total protein in Mojosari duck meat significantly. Even more interesting, the administration of cherry leaf flour significantly reduced the total fat content in P2 with a concentration of $6 \%$ (Table 2). However, increasing the concentration of $M$. calabura did not decrease the total fat content in the meat (Table-3). This study concludes that the administration of $M$. calabura with a concentration of $6 \%$ is the optimum concentration to obtain low-fat meat.

\section{CONCLUSION}

Cherry leaf flour is less effective in changing the levels of low-density lipoprotein significantly. Also, the provision of cherry leaf flour is not effective in increasing the highdensity lipoprotein significantly. However, cherry leaf flour is effective in reducing the total fat content of Mojosari duck significantly and increasing the protein content of Mojosari duck meat significantly.

\section{CONFLICTS OF INTEREST}

The authors declare that they have no conflicts of interest.

\section{REFERENCES}

1. Adriani, L. (2013). Blood glucose and triglyceride profile using Alpinia galanga (L.)/Lengkuas juice. Scientific Papers, Series D. Animal Science, 56, 300-304. http://animalsciencejournal.usamv.ro/pdf/vol.LVl/Art54.pdf

2. Adzitey, F., \& Adzitey, S. P. (2015). Duck production: has a potential to reduce poverty among rural households in Asian communities-a review. agris.fao.org

3. Alloubani, A., Nimer, R., \& Samara, R. (2020). Relationship between Hyperlipidemia, Cardiovascular Disease and Stroke: a Systematic Review. Current Cardiology Reviews. https://doi.org/10.2174/1573403×16999201210200342

4. Amaral, J. S., Santos, C. G., Melo, V. S., Costa, J., Oliveira, M. B. P., \& Mafra, I. (2015). Identification of duck, partridge, pheasant, quail, chicken and turkey meats by speciesspecific PCR assays to assess the authenticity of traditional game meat Alheira sausages. Food Control, 47, 190-195. https://doi.org/10.1016/j.foodcont.2014.07.009

5. Baskaran, G., Salvamani, S., Ahmad, S. A., Shaharuddin, N. A., Pattiram, P. D., \& Shukor, M. Y. (2015). HMG-CoA reductase inhibitory activity and phytocomponent investigation of Basella alba leaf extract as a treatment for hypercholesterolemia. Drug design, development and therapy, 9, 509. https://dx.doi.org/10.2147\%2FDDDT.S75056

6. Biswas, S., Banerjee, R., Bhattacharyya, D., Patra, G., Das, A. K., \& Das, S. K. (2019). Technological investigation into duck meat and its products-a potential alternative to chicken. World's Poultry Science Journal, 75(4), 609-620. https://doi.org/10.1017/S004393391900062X 
7. Böhm, V. (2012). Lycopene and heart health. Molecular nutrition \& food research, 56(2), 296-303. https://doi.org/10.1002/mnfr.201100281

8. Marinda,D. T. (2016). Pengaruh Pemberian Ekstrak Buah Kersen (Muntingia calabura) Terhadap Kadar Kolesterol Total Pada Mencit Hiperlipidemia (Doctoral dissertation, Universitas Airlangga). http://repository.unair.ac.id/id/eprint/66301

9. Franke, A. A., Cooney, R. V., Henning, S. M., \& Custer, L. J. (2005). Bioavailability and antioxidant effects of orange juice components in humans. Journal of agricultural and food chemistry, 53(13), 5170-5178. https://doi.org/10.1021/jf050054y

10. Hirano, R., Sasamoto, W., Matsumoto, A., Itakura, H., Igarashi, O., \& Kondo, K. (2001). Antioxidant ability of various flavonoids against DPPH radicals and LDL oxidation. Journal of nutritional science and vitaminology, 47(5), 357-362. https://doi.org/10.3177/jnsv.47.357

11. Layli, A. N., Djamiatun, K., \& Kartasurya, M. I. (2017). Pengaruh Ekstrak Daun Kersen (Muntingia calabura L) terhadap Kolesterol Darah, Soluble ICAM-1 dan Pembentukan Sel Busa pada Tikus dengan Diet Tinggi Lemak dan Kolesterol. Jurnal Kedokteran Brawijaya, 29(3), 202-208. http://dx.doi.org/10.21776/ub.jkb.2017.029.03.4

12. Lembong, J. F., Santa, N. M., Makalew, A., \& Elly, F. H. (2015). Analisis break even point usaha ternak itik pedaging (studi kasus pada usaha itik milik kelompok masawang di desa talikuran kecamatan remboken). ZOOTEC, 35(1), 39-45. https://doi.org/10.35792/zot.35.1.2015.6460

13. Mangaraj, M., Nanda, R., \& Panda, S. (2016). Apolipoprotein Al: a molecule of diverse function. Indian Journal of Clinical Biochemistry, 31(3), 253-259. https://doi.org/10.1007/s12291-015-0513-1

14. McAnlis, G. T., McEneny, J., Pearce, J., \& Young, I. S. (1998). Black tea consumption does not protect low density lipoprotein from oxidative modification. European journal of clinical nutrition, 52(3), 202-206. https://doi.org/10.1038/sj.ejcn.1600540

15. Mooradian, A. D., Haas, M. J., \& Wong, N. C. (2006). The effect of select nutrients on serum high-density lipoprotein cholesterol and apolipoprotein Al levels. Endocrine reviews, 27(1), 2-16. https://doi.org/10.1210/er.2005-0013

16. Nagara, B. G. (2015). Antioxidant Activity: Root, Leaves and Fruits Aqueous Extracts of Muntingia Calabura. JIPBS, 2(4), 363-368. http://www.jipbs.com/

17. Listiantini, N. A. (2017). Efek Ekstrak Etanol Daun Kersen (Muntingia calabura L.) Pada Kolesterol Total Darah Mencit Jantan Yang Dipapar Oleh Pakan Tinggi Lemak (Doctoral dissertation, Universitas Airlangga). http://repository.unair.ac.id/id/eprint/66427

18. Nooreen, Z., Rai, V. K., \& Yadav, N. P. (2018). Phytopharmaceuticals: A new class of drug in India. Ann. Phytomed, 7(1), 27-37. 10.21276/ap.2018.7.1.4

19. Nurhuda, M., Kholista, M. A., Ismi, Y., Maulidiya, N., Hariyadi, H., \& Hakim, R. R. (2018). Effectiveness of Cherry Leaf Extract (Muntingia Calabura) with Different Levels as Treatment of Seeds of Sangkuriang Catfish (Clarias Gariepinus) Infected by Trichodina SP. IJOTA (Indonesian Journal of Tropical Aquatic), 1(1), 41-49. https://doi.org/10.22219/ijota.v1i1.5980

20. Onbaşilar, E. E., \& Yalcin, S. (2018). Fattening performance and meat quality of Pekin ducks under different rearing systems. World's Poultry Science Journal, 74(1), 61-68. https://doi.org/10.1017/S004393391700099X

21. Puspasari, A. F., Agustini, S. M., \& Illahika, A. P. (2016). Pengaruh Ekstrak Daun Kersen (Muntingia calabra L.) terhadap Profil Lipid Mencit Putih (Mus musculus) Jantan yang Diinduksi Minyak Jelantah. Saintika Medika: Jurnal Ilmu Kesehatan dan Kedokteran Keluarga, 12(1), 49-55. https://doi.org/10.22219/sm.v12i1.5260

22. Putra, A. S., Sutrisna, R., \& Santosa, P. E. (2016). Kondisi Fisiologis Itik Mojosari Betina yang Diberi Ransum Berbeda. Jurnal Ilmiah Peternakan Terpadu, 4(2). http://dx.doi.org/10.23960/jipt.v4i2.p\%25p

23. Putri, C. A., Yuliet, Y., \& Khaerati, K. (2018). Efektivitas Ekstrak Daun Kersen (Muntingia calabura L.) Terhadap Penurunan Kadar Kolesterol Total Tikus Putih Jantan (Rattus norvegicus L.) Yang Diinduksi Pakan Tinggi Lemak. Biocelebes, 12(1). https://bestjournal.untad.ac.id/index.php/Biocelebes/article/view/10030 
24. Sopandi, D., Saraswati, T. R., \& Yuniwarti, E. Y. W. (2019). Effects of Kersen Juice and Lakum Leaf Extract on Lipid Profile of White Rats with Hyperlipidemia. Biosaintifika: Journal of Biology \& Biology Education, 11(3), 345-351. https://doi.org/10.15294/biosaintifika.v11i3.20813

25. Sulistyoningsih, M., Rakhmawati, R., \& Septiyanto, A. A. (2018). Pengaruh Pemberian Jahe, Kunyit dan Salam Terhadap Kadar Asam Urat dan Glukosa Darah pada Bebek. Jurnal Peternakan Indonesia (Indonesian Journal of Animal Science), 20(2), 78-83. https://doi.org/10.25077/jpi.20.2.78-83.2018

26. van Dam, R. M., Naidoo, N., \& Landberg, R. (2013). Dietary flavonoids and the development of type 2 diabetes and cardiovascular diseases: review of recent findings. Current opinion in lipidology, 24(1), 25-33. 10.1097/MOL.0b013e32835bcdff

27. Wilcox, L. J., Borradaile, N. M., de Dreu, L. E., \& Huff, M. W. (2001). Secretion of hepatocyte $a p o B$ is inhibited by the flavonoids, naringenin and hesperetin, via reduced activity and expression of ACAT2 and MTP. Journal of lipid research, 42(5), 725-734. https://doi.org/10.1016/S0022-2275(20)31634-5

28. Wiyati, T., Dewanti, E., \& Chairunnisa, W. F. (2020). Aktivitas Antihiperlipidemia Daun Kersen (Muntingia calabura L.) Pada Hamster Kondisi Hiperglikemia dan Hiperkolesterol. Farmasains: Jurnal IImiah IImu Kefarmasian, 7(2), 59-66. https://doi.org/10.22236/farmasains.v7i2.5616

29. Zakaria, Z. A., Mohamed, A. M., Jamil, N. M., Rofiee, M. S., Hussain, M. K., Sulaiman, M. R., ... \& Salleh, M. Z. (2011). In vitro antiproliferative and antioxidant activities of the extracts of Muntingia calabura leaves. The American Journal of Chinese Medicine, 39(01), 183-200. https://doi.org/10.1142/S0192415X11008749

30. Zhang, B., Haitao, L., Zhao, D., Guo, Y., \& Barri, A. (2011). Effect of fat type and lysophosphatidylcholine addition to broiler diets on performance, apparent digestibility of fatty acids, and apparent metabolizable energy content. Animal Feed Science and Technology, 163(2-4), 177-184. https://doi.org/10.1016/j.anifeedsci.2010.10.004

31. Zou, Y., Lu, Y., \& Wei, D. (2005). Hypocholesterolemic effects of a flavonoid-rich extract of Hypericum perforatum $L$. in rats fed a cholesterol-rich diet. Journal of agricultural and food chemistry, 53(7), 2462-2466. https://doi.org/10.1021/jf048469r 